\title{
CONSUMER RIGHTS PROTECTION OF TANGERANG CITY PDAM THROUGH SERVICE QUALITY*
}

\author{
Josefin Mareta** \\ Research and Development, The Agency of Law and Human Rights \\ Jalan H.R. Rasuna Said Kavling 4-5 Kuningan, Jakarta Selatan, 12940
}

\begin{abstract}
Tangerang City PDAM as a public water company is inseparable from the risk of consumer rights violation. This research was conducted to know the rights protection of Tangerang City PDAM consumer, which is based on the service quality. This research used combined method of quantitative and qualitative methods. The results showed the customer dissatisfaction of the service quality. The inadequate quality of service reflects the non-fulfilment of consumer rights. The protection of PDAM consumer is based on the Law number 8 of year 1999 on Consumer Protection, which among others includes the right to claim compensation through class action.
\end{abstract}

Keywords: consumer rights, PDAM, service quality.

\section{Intisari}

PDAM Kota Tangerang sebagai perusahaan monopoli dalam penyelenggaraan pelayanan air bersih tidak terlepas dari resiko pelanggaran hak konsumen. Penelitian ini bertujuan untuk mengetahui perlindungan hak konsumen PDAM Kota Tangerang didasarkan pada pengukuran kualitas pelayanan. Penelitian ini menggunakan metode penelitian kombinasi dengan menggabungkan metode kuantitatif dengan kualitatif. Hasil penelitian menunjukkan ketidakpuasan konsumen terhadap kualitas pelayanan yang ada. Kualitas pelayanan yang tidak sesuai dengan harapan merefleksikan hak-hak konsumen belum terpenuhi. Perlindungan hak konsumen PDAM Kota Tangerang didasarkan pada Undang-Undang Nomor 8 Tahun 1999 tentang Perlindungan Konsumen diantaranya hak menuntut ganti rugi melalui gugatan perwakilan.

Kata Kunci: hak konsumen, PDAM, kualitas pelayanan.

\section{Pokok Muatan}

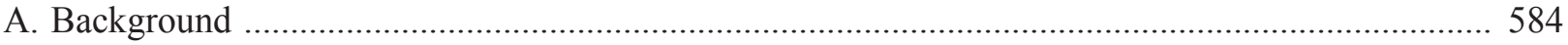

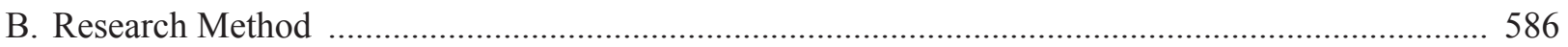

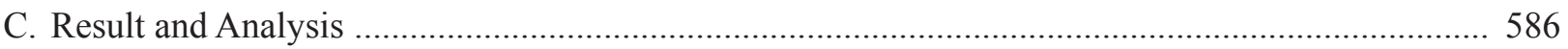

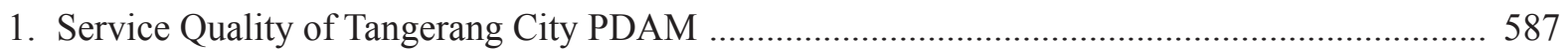

2. Consumer Rights Protection of Tangerang City PDAM …....................................................... 589

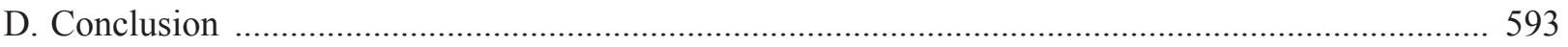

\footnotetext{
* This Research funded by DIKTI, 2015.

** Correspondence address: josefhin@gmail.com.
} 


\section{A. Background}

Water is a basic need that cannot be separated from human life. The provision of clean water is a particular concern of every country in the world, including Indonesia. Population growth, intensive development, and rising living standards led to the increasing need for clean water. Consequently, there is increasing demand from the community for the prime quality of service by the provider of clean water.

In 2002, the Committee on Economic, Social and Cultural Rights of the United Nations provides a more assertive interpretation of the article 11 and 12 of the Covenant on Economic, Social and Cultural Rights in which rights to water, is deemed cannot be separate from the other rights of human beings. Rights to water also include freedom to manage access to water. ${ }^{1}$ Another element of rights to water is its adequacy to ensure human dignity, life, and health. Adequacy of rights to water must not be interpreted narrowly, as only in terms of the quantity of volume and technology. Water should be treated as social and cultural goods, not merely as economic goods.

In Indonesia, local water companies (Perusahaan Daerah Air Minum-PDAM) are often viewed as businesses that provide essential services for the community. As stipulated in Article 1 paragraph 3 of Law Number 8 of 1999 on Consumer Protection, business is every individual or business entity whether they are legal entity or not, which are established, and domiciled or conducting activities within the jurisdiction of the Republic of Indonesia, either singularly or jointly with the agreement of business activities in various economic fields.

In 2013, the PDAM service has reached 9.8 million household connections. The water production volume is 3.2 billion liters without considering the water leakage rate of 32.8 percent. The majority of its customer often complained about the quality of clean water provided by the PDAM, especially its turbidity and odor. ${ }^{2}$

The Law Number 7 Year 2004 on Water

Resources is the law that governs the management of water resources. In principle, this law will regulate two basic components of water resources management, namely water utilization and water exploitation rights. These two rights to water resources management were meant to increase access to the benefits of water to its water-using community. One of the controversies that arise from the emergence his law one is the stipulation of water exploitation rights, in which this right can be granted to an individual or entity with the permission of the national or local government. The controversy arises from the possibility of a monopoly or control of water, considered as a natural resource, which is a fundamental human need.

The Law on Water Resources opens huge opportunities for commercialization of water resources. There are indications that, through the provision of the right to cultivate, the private sector will use the opportunity to engage widely in water utilization, not only for clean water and drinking water but also in the fulfillment of irrigation water needs for agriculture. The Government Regulation Number 16 Year 2005 on Drinking Water Supply System (Sistem Penyediaan Air Minum-SPAM) further confirmed the strong role of the private sector in water management. In fact, the act asserted, that SPAM development is the responsibility of the central government or local government. As such, the organizers are state/local enterprises. The right to use water according to this law on water resources will only benefit the managers who utilized the water resource, not the consumers.

The PDAM have an obligation to provide public service. The nature of public service is to provide excellent service to the community. This is the embodiment of the obligations of government apparatus as a public servant, as defined in the Decree of the Minister of Administrative Reform

Arinto Nurcahyono, et al, "Hak Atas Air dan Kewajiban Negara dalam Pemenuhan Akses terhadap Air", Jurnal Mimbar, Vol. 31, No. 2, Oktober 2015, p. 391.

Redaktur Kompas, “Jutaan Sambungan jadi Syarat Penuhi Akses Air”, Kompas, 5 Maret 2015. 
Number 63 Year 2004 on Principles and Nature of Public Service. Public service quality has become very important because, since the decentralization, the number of service activities that should be handled by local governments has grown rapidly and the interaction between the region and the public has increased in its intensity.

The PDAM in Indonesia, including PDAM Tirta Benteng in the city of Tangerang, is tasked with the management and provision of water services to improve the welfare of the community. It is socially oriented, established with the purpose of providing optimal water services for the society. In the provision of drinking water services, the PDAM Tirta Benteng supplied drinking water and related technical services. The PDAM Tirta Benteng in the city of Tangerang serves several areas in the district Neglasari, Batuceper, Cipondoh, Benda, Jatiuwung, Ciledug, and Pinang ${ }^{3}$ with 27.526 customers in 2014.

Public service businesses run by state-owned enterprises or areas such as electricity, water, and telephone are very vulnerable to the violation of consumer rights. Using similar logic, the PDAM Tirta Benteng in Tangerang City, as a public service business, is also vulnerable to the risk of violation of consumer rights. Customer complaints will not happen if there is a satisfactory quality of service. The quality of these services can ultimately provide several benefits, including the establishment of a harmonious relationship between the providers of goods and services to the customers; provide a good foundation for the creation of customer loyalty and generating a word-of-mouth marketing by means of customer recommendation which is profitable for the service providers. ${ }^{4}$

Quality has a close relationship with the customer satisfaction. Quality gives an incentive to customers to establish strong ties with a company. Quality should start from the needs of customers and end with customer perception. This means that the image quality is better when it is not based on the perception of the service provider, but based on its customer perception. Customer perception of service quality is a thorough assessment of the benefits of a service. The quality of service is described as a statement of attitude, relationships resulting from a comparison between expectations and performance. Customer expectation is formed based on several factors, including past experience, the opinion of peers, information and any brand promises made by the company. ${ }^{5}$

Consumer satisfaction is influenced by the perception of service quality, product quality, price and other personal and situational factors. One of the factors that determine customer satisfaction is the customer perception of the quality of services that focuses on five dimensions of service quality, which are tangibility, reliability, responsiveness, assurance and empathy. ${ }^{6}$

The PDAM is an enterprise run by the local government to operate as a community service agency. The PDAM as public sector organizations gives priority to the satisfaction of the community through the provision of public goods and services of high quality at an affordable price. In order to increase customer satisfaction, the PDAM should be able to identify the factors that influence customer satisfaction and then attempt to measure such customer satisfaction, because the macro purpose of public sector organizations is to create a welfare society.

Customer satisfaction will ultimately lead to other performance successes, namely financial performance. As a public service oriented company, the PDAM must be properly managed based on the

\footnotetext{
Juwarin Pancawati, “Ketersediaan Lahan Resapan Air di Kota Tangerang”, Jurnal Ilmu Pertanian dan Perikanan, Vol. 2 No. 1, Juni 2013, p. 14.

4 Dwi Wahyu Pril Ranto, "Pengaruh Kualitas Pelayanan Terhadap Kepuasan Pelanggan Berbelanja Pada Toko Modern di Yogyakarta", Jurnal Bisnis Teori dan Implementasi, Vol. 6, No.1, Februari 2015, p. 21.

Mohammad Assegaf, "Pengaruh Kualitas Pelayanan Terhadap Kepuasan konsumen Studi Pada Perusahaan Penerbangan PT. Garuda Di Kota Semarang”, Jurnal Ekonomi dan Bisnis Unisulla Semarang, Vol. 10 No. 2, Juli 2009, p. 5.

6 Rustika Atmawati dan Wahyuddin, “Analisis Pengaruh Kualitas Pelayanan Terhadap Kepuasan Konsumen Pada Matahari Departement Store di Solo Grand Mall”, Jurnal Ekonomi Manajemen Sumber Daya, Vol. 5, No. 1, Juni 2004, p. 55.
} 
principles of corporate economy, able to maintain the viability of the company, and should be seamlessly able to serve the drinking water needs of its customers in sufficient quantities.

Based on the background above, problems can be formulated as follows: First, how is the analysis of service quality of Tangerang City PDAM? Second, how is the protection of consumer rights of Tangerang City PDAM? The following research hypotheses were developed: (1) $\mathrm{H} 0=0$ : there is no gap between the expectations of consumers with the services received by consumers. (2) $\mathrm{H} 1 \neq 0$ : there is a gap between the expectations of consumers with the services received by consumers.

\section{B. Research Method}

This study uses a combination of research methods (mixed methods). This research combines two forms of research (qualitative research and quantitative research). ${ }^{7}$ Qualitative research is carried out by conducting in-depth interviews, while the quantitative research focused on respondents, namely consumers of the PDAM of Tangerang City. Quantitative data analysis is conducted by analyzing the gap between the level of importance (expectations) and performance (perception) of the PDAM of Tangerang City. Furthermore, these results are equipped with qualitative data with an in-depth interview to formulate an analysis of consumer rights protection conducted by the PDAM of Tangerang City.

Data collection techniques used in this study were: (1) Study of literature: by reviewing documents, legislation, research studies, books, and other literature; (2) field studies: in-depth interviews as well as distributing questionnaires to the respondents. In analyzing the research data, the researcher used a descriptive qualitative method, which was complemented with an analysis of quantitative data. The quantitative analysis uses methods of determining service quality to perform a gap analysis.

The first step includes grouping items into five dimensions question, and calculating the average value of the performance/perceptions and importance/expectations of customers. The average value obtained from the scores of the level of performance were then divided by the number of respondents in each dimension, while the average value of the importance value derived from the importance score was also divided by the number of respondents in each dimension. It is then possible to calculate the gap value. Positive or zero gap score shows consumer satisfactions. On the other hand, negative gap score shows perceived consumer dissatisfaction. Smaller perception than expectations value $(\mathrm{P}<\mathrm{E})$ indicates a consumer negative perception towards the service they received. This will lead to customer dissatisfactions. The testing of hypothesis in this study was conducted by using t-test. The t-test method that was used in the study is the two independent samples t-test or paired sample t-test, which means that the variables were derived from the same population. Paired samples t-test was used to test whether there is a significant gap between the customer expectations value and their perception value. Testing is done by comparing $t$ arithmetic with $t$ table. ${ }^{8}$ Qualitative analysis will analyze and compare the findings with research results with relevant theories to answer the research question. Qualitative analysis will also provide a description of the results of the study based on the theoretical framework.

\section{Result and Analysis}

Public services essentially are the fulfillment of the wishes and needs of society by state officials. States were established by the society with the aim to improve the welfare of the community. In essence, the state, in this case, the government (bureaucrats), must be able to meet the needs of the community. ${ }^{9}$

Regulation of The Ministry of Health of The

\footnotetext{
John W. Creswell, 2010, Research Design: Qualitative, Quantitative, and Mixed Approach, Pustaka Belajar, Yogyakarta, p. 316. Imam Ghozali, 2005, Program Aplikasi Analisis Multivariate Dengan Program IBM SPSS, Universitas Diponegoro, Semarang, p. 45. Lijan Poltak Sinambela, 2008, Reformasi Pelayanan Publik: Teori, Kebijakan dan Implementasi, Bumi Aksara, Jakarta, p. 45.
} 
Republic of Indonesia Number 907/Menkes/SK/ VII/2002 regarding The Requirements of Drinking Water Quality defines the notion of clean water as such water being used for everyday purposes of which its quality meets health requirements and consumable after cooking. The standard for the quality of water is the absence of inorganic and organic materials in it. In other words, highquality portable water should be free from bacteria, chemicals, and other toxic, hazardous wastes.

The consumer's hope is what the consumer thinks should be served by the service provider, while the consumer perception is how the consumer view or rate the services that have been received from the service provider. After enjoying the services provided, the consumer will compare between their expectations and their perception of the service received. There are several possibilities: ${ }^{10}$ (1) If the perception is smaller than the expectation, $(\mathrm{P}<\mathrm{E})$, the consumer will give a negative presumption to the service received. This will lead to dissatisfaction of the consumer; (2) If the perception is equal to expectations, $(\mathrm{P}=\mathrm{E})$, the consumer will provide a much more neutral assumption, in accordance with the service received. This will make the consumer feel satisfied with the services; and (3) If the perception is greater than the expectation, $(\mathrm{P}>\mathrm{E})$, the consumer will give a positive response to the service received. This will make the consumer will feel very satisfied with the service (customer delight).

Bates and Hoffman explained that service quality is an assessment of the process of customer service delivery. ${ }^{11}$ Meanwhile, Parasuraman defines the quality of service as the customer perception of the services they receive. ${ }^{12}$ Rangkuti defines customer satisfaction as the customer response to the mismatch between the previous level of importance and actual performance they felt after using the service. One of the factors that determine customer satisfaction is the customer perception of the quality of services that focus on responsiveness, reliability, empathy, assurance and tangible. ${ }^{13}$

\section{Service Quality of Tangerang City PDAM}

The value of the expectation and perception of service quality was measured using the indicators of service quality, namely tangibility, reliability, responsiveness, assurance and empathy.

Table 1. Average Score of Service Quality Dimensions

\begin{tabular}{|c|c|c|c|}
\hline \multirow[t]{2}{*}{$\begin{array}{l}\text { Dimensions of } \\
\text { Service Quality }\end{array}$} & \multicolumn{2}{|c|}{$\begin{array}{l}\text { Score Average of } \\
\text { Dimension }\end{array}$} & \multirow{2}{*}{$\begin{array}{c}\text { Gap Aver- } \\
\text { age of } \\
\text { Dimensions }\end{array}$} \\
\hline & $\begin{array}{l}\text { Expecta- } \\
\text { tion }\end{array}$ & $\begin{array}{l}\text { Percep- } \\
\text { tion }\end{array}$ & \\
\hline Tangibility & 4.55 & 3.94 & -0.61 \\
\hline Reliability & 4.62 & 3.61 & -1.01 \\
\hline Responsiveness & 4.45 & 3.84 & -0.61 \\
\hline Assurance & 4.56 & 4.02 & -0.54 \\
\hline Empathy & 4.56 & 4.01 & -0.55 \\
\hline Average & 4.55 & 3.89 & -0.66 \\
\hline
\end{tabular}

Source: Processed Primary Data , 2015.

The results showed that the overall indicator of the services quality provided by the PDAM of Tangerang City has a negative gap score. Perception value is smaller than expectations $(\mathrm{P}<\mathrm{E})$ so that the consumer gives a negative presumption against the services they have received. This creates customer dissatisfaction. The average gap value of the service quality indicators for the PDAM of Tangerang City is -0.66 . We can also see that some indicators have a negative gap score with an average value above -0.66 including indicators numbers 2 (availability of leaflets about the service information), 8 (the accuracy of the result of recording water bills), 9 (clarity of water quality colorless, odorless), 10 (water distribution continuity), 11 (the quantity of

10 Christopher Lovelock, et al., 2001, Services Marketing: An Asia-Pacific Perspective $2^{\text {nd }}$ edition, Pearson Education, Sydney, p. 30.

1 John E. G. Bates and Douglas Hoffman, 1999, Managing Services Marketing: Text and Readings, The Dryden Press Harcourt Brace College Publisher, Orlando, p. 338.

12 Valeri A. Parasuraman, et al., “Conceptual Model of Service L. and Its Implications for Future Research”, Journal of Marketing, No. 49, 1985, p. 56.

13 Freddy Rangkuti, 2002, Measuring Customer Satisfaction Teknik Mengukur dan Strategi Meningkatkan Kepuasan Konsumen, Gramedia Pustaka Utama, Jakarta, p.15. 
water that never diminished), 12 (security PDAM pipe), and 17 (the quickness of officers to respond customer complaints).

Indicators that have the lowest gap in comparison to the others is indicator 14 (services speed of the payment process) with a value of -0.33 , while the 5 indicators that have the highest gap lies in the indicator 8 (the accuracy of the water billing records) with a value of $-1,11$; Indicators 9 (clarity of water quality (colorless, odorless) with a value of -1.49; indicator 10 (smooth distribution of water) with a value of -1.76 ; indicator 11 (the non-diminishing quantity of water) with a value of -1.57; and indicator 12 (water network security) with a value of -1.05 . The effort to improve the service needs to be focused on specific indicators to have a significant impact on increasing the services provided by the PDAM of Tangerang City and minimizing existing gaps. Moreover, the results also illustrate the value of the average gap in each dimension. These results show the largest negative gap score was on the dimension of reliability with a value of -1.01 , followed by the dimensions of physical evidence (tangibility) and responsiveness with a value of -0.61 .

Paired Sample t-test was used to test whether there is a significant gap between the value of customer expectations and the value of customer perception. Paired sample t-test compared the mean difference between expectations and perceptions, in which the comparison is performed on the same sample group. Testing is done by comparing $t$ arithmetic with $t$ table. The mean value per variable was inputted into SPSS 20 software, both for the expectations and perceptions value of the customer. The testing for the hypothesis was: (1) $\mathrm{H} 0=0$, meaning there is no gap between the expectations and perceptions. (2) $\mathrm{H} 1 \neq 0$, meaning that there is a gap between expectations and perceptions.

Criteria for acceptance Based Sig : (1) If sig > 0.05 then $\mathrm{H} 0$ is accepted. (2) If sig $<0.05$ then $\mathrm{H} 1$ is accepted. Based on the $t$ arithmetic (in $t$ minus sign is not considered), If $\mathrm{t}$ arithmetic $<\mathrm{t}$ table then $\mathrm{H} 0$ is accepted. Besides, if $t$ arithmetic $>t$ table then $\mathrm{H} 1$ is accepted. With significance level of 5\% $(\alpha=0.05)$, the $t$ table for degree of freedom $(\mathrm{df})=\mathrm{n}-1$, obtained $\mathrm{t}$ table $=1.984$

Table 2. Results Paired of Samples t-test

\begin{tabular}{lccc}
\hline $\begin{array}{c}\text { Dimensions of } \\
\text { Service Quality }\end{array}$ & t arithmetic & t table & Sig. \\
\hline Tangibility & 5.993 & 1.984 & 0.000 \\
Reliability & 8.346 & 1.984 & 0.000 \\
Responsiveness & 6.479 & 1.984 & 0.000 \\
Assurance & 6.503 & 1.984 & 0.000 \\
Empathy & 6.042 & 1.984 & 0.000 \\
\hline
\end{tabular}

Source: Processed Primary Data (2015)

The results of the calculation of Paired Sample t-test for each of the indicators on the dimensions of service quality produce $\mathrm{t}$ arithmetic greater than $\mathrm{t}$ table, then the hypothesis $\mathrm{H} 0$ refused and H1 accepted, which means there is a gap between customer expectations and their perceptions. With the results of significance value of $0.000(<0.05)$ it could be concluded that the mean difference between expectation and perception for the PDAM of Tangerang City service quality is significant, that is, the customer perception of service quality provided by the PDAM of Tangerang City was not in accordance with the expectations of their customer.

Figure 1. Model of Service Quality Gap Model of Service Quality

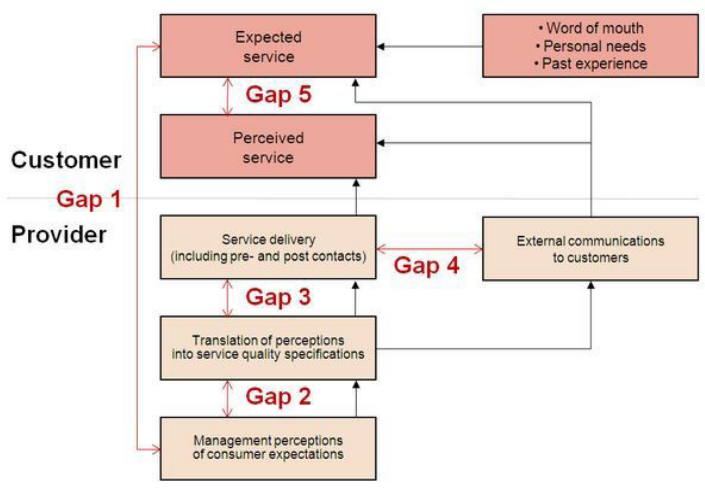

Source: Parasuraman, 2002. ${ }^{14}$ 
The calculation of the average of expectation and perception of the indicators and dimensions that influence customer satisfaction show that there is a gap between the services expected and the perceived services received (Gap 5) from the PDAM of Tangerang City. Gap 5 in the figure above shows that the disparities are based on the recipient of the services (consumer), which means that the assessment of service quality and customer satisfaction completely in the hands of the customer. The occurrence of this gap indicates that the quality of services that was provided by the PDAM of Tangerang City has not been in line with expectations or needs of customers, resulting in customer dissatisfaction.

\section{Consumer Rights Protection of Tangerang City PDAM}

Consumer protection laws are the overall principles and legal rules that regulate and protect consumers in their relationship with the supplier of goods and/or services and any problems arise from that relationship. ${ }^{15}$ Article 1, paragraph 1 on The Law number 8 the year 1999 on Consumer Protection stated that consumer protection is every effort that guarantees the legal certainty of consumer protections.

The quality of service is not in accordance with the expectations of consumers, causing dissatisfaction reflecting that the consumer rights have not been fulfilled properly. Law Number 8 of 1999 on Consumer Protection has been set to regulate the rights of consumers. The Protection of consumer rights by the PDAM of Tangerang City, are as follows:

\section{a. The Rights to Comfort, Security, and Safety in Consumption of Goods and/or Services}

Based on the findings, it seemed that the provision of clean water by the PDAM of Tangerang City was not in accordance with the standards required of them, where the quality of the water is not clear, colorless and odorless; the distribution of water is not smooth, the quantity of water is reduced and often stopped, as well as leakage in the pipeline. In order to protect the interests of consumers, Article 8 of Law Number 8 Year 1999 includes the prohibition of businesses to produce and trade goods or services that do not meet the required standard, such as in the context water supply services provided by the PDAM of Tangerang City.

b. The Rights to Correct, Clear, and Honest Information About The Condition and Guarantee of The

\section{Goods and/or Services}

Based on the results of the study, the consumer said that they have not received clear information on products and services, as seen from the unavailability of user manuals or leaflets about the service information. Article 8 of Law number 8 the year 1999 banned incorrect and inaccurate information which are misleading the consumers in accordance with the consumer rights to correct, clear and honest information about the condition and guarantee of the goods and/ or services.

\section{c. The Rights to be Heard when Having Opinions and Complaints on Goods and/or Services Provided}

In response to the problem of service quality, there are consumers complain directly to the PDAM. According to the research, consumers felt that the officer was not quick and responsive in dealing with customers complaints. The assortment of media for customer complaint provided by the PDAM, such as through the Call Center, SMS, phone, email, or customers direct visit to the central office to directly report their complaints. Steps taken by the complaints

15 A.Z. Nasution, 1995, Konsumen dan Hukum, Pustaka Sinar Harapan, Jakarta, p.69. 
resolution department of the Tangerang City PDAM is through non-litigation, and the settlement of dispute never reach the court because the PDAM always try to resolve customer complaints either about the technical problems (leaking pipes, water meter) and non-technical (administrative issues).

d. The Rights to Get Advocacy, Protection, and Mediation in Consumer Protection

Another effort taken by consumers to obtain their rights is to denounce the matter to the non-governmental consumer protection organization in the City of Tangerang, one of which is Yayasan Lembaga Perlindungan Konsumen Handaini (YLPKH). YLPKH step in to provide protection to the consumers of PDAM in Tangerang, one of their methods is to engage in dialogue or forum between customers and PDAM. The process of disputes settlement with YLPKH intermediaries is through mediation. Another nongovernmental consumer protection organization which handles cases of consumer disputes that occur in the community is Yayasan Lembaga Konsumen Indonesia (YLKI).

YLKI receive and follow up complaints from consumers who experienced problems because they are not satisfied with the goods or services received from businesses, by acting actively or passively. Actively acting is the YLKI actively monitoring and following up letters to the media, while passively, if the initiative comes from the consumers by directly contacting YLKI and reported the problem. YLKI invites the parties to mediate and reach an agreement between them. The outcome of the mediation is a peace agreement between the parties to agree or disagree in which case it means the deadlock.

\section{e. The Rights to Receive Guidance and Consumer Education}

The main factor of the weak position of the consumer is their low level of education or public knowledge in the field of consumer protection. Consumer education aims to equip consumers to become responsible market participants. It is a shared responsibility between government, businesses and consumers as a pillar of the economy. The most important effort is to provide sufficient knowledge to the public as users of the product for consumers to understand their obligations as being critical and cautious in using the product so as to eliminate losses. In other words, educate people to become smart consumers (smart with their rights and obligations).

The supervisory system by the consumer increased awareness and knowledge about the quality of the products it uses and ways of using national products. Consumers with awareness and a high level of knowledge regarding the quality and usability of a product, on the one hand, can be stretched itself against the use of products that do not qualify and are not required. A high level of public awareness will encourage manufacturers to be more careful in maintaining the quality and safety of their products.

\section{f. The Rights to Obtain Compensation and/or Replacement if The Goods and/or Services Received are not in Accordance with Standards or Agreement}

The basics of reference to realize the consumer protection, are the legal relationship between the seller and the consumer in good faith; the sellers and consumers contractual relationship is clearly formulated; consumers as a economic agents; consumers who suffered losses due to defective can receive adequate compensation; and the parties be 
given choice for dispute settlement, have stressed the importance of giving consumers the right to obtain compensation for damages and/ or replacement if it was not in accordance with the agreed or not in a condition properly. The agreements between businesses and consumers is a common thing in their relationship because the agreement is an engagement made by both sides in order to hold each party accountable for their rights, obligations, and responsibilities, so it will make it easier to point the offending party in cases of disputes. But what often materialized is an unbalanced relationship between the rights and obligations of businesses and consumers.

The agreement between consumers and the PDAM did not include consumer rights but focuses more on some of the obligations that must be met by consumers. Whereas The Law number 8 the year 1999 has clear stipulations regarding the obligations of businesses (Article 7), which should also be reflected in the agreement between the customer and the PDAM.

The implication is that when there is a loss on the part of the consumer, it would be difficult for the consumer to assert their rights to the PDAM because from the beginning the consumer has approved the contents of the affidavit. The letter of agreement also did not contain the provision regulating should the PDAM defaulted on their obligation, such as in the event of delayed installation, no sanctions are to be imposed to the PDAM or compensation to be paid to consumers for such delay. The unbalanced relationship is also seen in the enforcement of consumer obligation where the consumer will be disconnected from their water service without prior notice should they fail to pay their water bills within a specified time.

Based on the research results, in most cases, customers do not have sufficient knowledge concerning their rights and obligations, including the right to redress and any compensation related to losses incurred through the use of the goods or services of PDAM. Law number 8 the year 1999
Article 19 states that businesses are responsible for providing compensation for damage, contamination, and/or loss of customers due to the consumption of goods and/or services produced or traded. Compensation can be either of refund or replacement of goods and/or services similar or equivalent value or a health care and/or donations in accordance with the provisions of the legislation in force. The indemnity will be carried out within a period of seven (7) days after the date of the transaction.

In the event of claims for compensation from the consumer, then according to Article 28 of Law number 8 of 1999, proof of the presence or absence of errors in the intestine claim for compensation as referred to in Article 19, Article 22 and Article 23 of Law number 8 of 1999 is a burden and responsibility of businesses. Then in Article 23, it is mentioned that businesses that refuse and/or does not respond and/or do not meet the compensation demanded by the consumers as referred to in Article 19, paragraph 1 , paragraph 2 , paragraph 3 , and paragraph 4 , can be sued by consumer dispute settlement agency (Badan Penyelesaian Sengketa Konsumen - BPSK) or prosecuted in the judiciary in the consumer/ plaintiff's domicile. The principle of liability is based on negligence/fault with the burden of proof, thus if the consumer claims for damages due to the quality of drinking water services that do not meet the standards, the PDAM can perform reverse authentication.

Based on the principle of liability based on negligence or fault with the burden of proof, if the consumer claims for damages due to the quality of water services that do not fulfill the standards, the PDAM of Tangerang City can perform reverse authentication. In case due to customer error, then PDAM can not charge for compensation claim to customers, example the compensation claim from customers because the large water bill, then PDAM discovered a leak in a pipe inside the channel the customer's home where according to the provisions that leak pipe inside the customer's home is the 
responsibility of the customers so that compensation claim filed by the customer on the amount of water bill can not be charged to the PDAM.

The factors causes the weak position of the consumer are as follows: (a) the low level of consumer awareness of their rights; (b) people do not know about their rights, where the rights can be distributed if it got into trouble or lack of a standard goods or services; (c) people don not have desire to claim their rights; (d) the judicial process is complicated and takes a long time; (e) The weak consumer position because of a contractual relationship that is not balanced or difficult to interact with producers.

Article 46 paragraph 1, letter b of Law Number 8 year 1999 with description mentions that the group of consumers who have an interest as well as the fact that the same may file a lawsuit against the perpetrators of the business class action. The similarity of interests and the facts can be seen from any agreements or evidence of the same.

In civil cases, if a consumer has a legal relationship in the form of an agreement with the other party and another party violates the agreement were agreed upon, then the consumer is entitled to sue his opponent by subterfuge in default. If there is no agreement, the consumer still has the right to sue civilly through the unlawful act. In that conception, someone is given the opportunity to sue if there: the existence of an unlawful act; production fault; consumer disadvantage; and a causal relationship between the unlawful act to the losses experienced by consumers. In the consumer protection laws, the aspects of the agreement are the very important factor although not an absolute factor that has to be present, the agreement is one source of the birth of the engagement. ${ }^{16}$

The agreement between the consumer and the PDAM basically uses the standardized form of agreement, which it's supporting document, and applies equally to every consumer. However, the agreement contains only the obligation of the consumer and sanctions if the consumer does not comply with its obligations. The agreement also does not regulate the provision should the PDAM reneges on its obligation to the consumers, nor that it contained any form of punishment or sanction leveled on the PDAM or compensation for customers on such instances.

Through the unlawful act, the consumer of PDAM was given the right to file a lawsuit should all of its required elements are met. The consumer of the PDAM can, by means of a class action, files a lawsuit against any unlawful act perpetrated by The PDAM, as long as it was supported with enough evidence which proves the following: the action was conducted by the PDAM; the act was unlawful; the presence of violation in the PDAM actions; the element of customer losses; as well as the causal relationships between actions PDAM with customer losses.

Besides the consumer protection laws number 8 the year 1999, the state also provides protection against people's right to water through the control of water by the state. The Cancellation of Law on Water Resources (number 7 the year 2004) and six other government regulations deriving from it resulted in the loss of legal protection for water privatization. The Constitutional Court ruled that water resource is a part of human rights. Guaranteeing that the state still holds tenure over the water was a requirement that cannot be excluded in assessing the constitutionality of water resources. This guarantee is seen in the six basic principles of water resources management restrictions, namely: (a) The control of water should not interfere, let alone negate or override the people's rights to water; (b) The State shall fulfill people's rights to water as access to water is a human rights; (c) Utilization of water should consider the preservation of life as one of human rights; (d) The supervision and control by the state over the water is absolute; (e) The main priority is to give control over water to the state/ local enterprises as the continuation of the rights of 
the state to control water resources; and (f) Private entities will still be able to have control over water resources under the state-specific and restricted conditions.

Water privatization does carry a number of consequences. First, people are losing access to water resources. Privatization will be the entrance for the private sector to take control of water resources. Second, the management of water resources under the market mechanism is intended to accumulate profit. In this kind of situation, everyone is required to spend money in order to access water resources. Consequently, water resources will become an exclusive commodity that can only be accessed by the upper and middle classes, therefore the people belonging to lower middle income will have a difficult time when accessing water resources. Third, privatization removes the responsibility of the state to provide water resources for the people. Conversely, no one can guarantee that the private sector would do a better job of managing water resources such as in the context of Jakarta, where the presence of the private sector failed to ensure that all residents of Jakarta have access to clean water.

In the City of Tangerang, the cooperation agreement between the PDAM with the private sector (PT Moya Indonesia) is also still problematic. The target of installing 8,000 direct connections in Taman Royal Housing at Cipondoh District, part of the development for Zone 1 (Cipondoh, Neglasari, Benda and Batu Ceper) has not been achieved since 2012. During the two years of cooperation, the company has only managed to build a new water installation with a capacity of 500 liters/second over 1 hectare of land in the Neglasari district.

Basically, the causes of contamination of the PDAM is the source of water used as raw materials for processing drinking water as well as a disruption of the distribution of processed drinking water to consumers. The clean water crisis in urban areas is generally caused by the pollution of rivers by household and industrial waste. The river water was then used as raw materials which were processed by the PDAM to produce clean water. Increasingly polluted raw water would result in higher cost of processing. The government gave the right to manage water resources to the private sector because they cannot finance the operating costs of expensive water management. However, when the water management was handed over to private companies, the government lost the power to participate in supervising the company's performance. As a result were the most expensive cost of subscriptions, limited quantity, and poor quality.

The six basic principles of water resources management restriction, however, still guarantee an opportunity to the private sector to manage water resources as long as they meet the requirements. Private sector involvement to provide clean water to the community is still needed because it takes a large investment to build facilities to process clean water. Concerning any form of cooperation conducted before the Constitutional Court decision, the cooperating parties can propose an evaluation of public-private partnership contract or renegotiation of cooperation contract. This measure is done to improve existing contracts to accommodate the six basic principles of natural resource management as set by The Constitutional Court.

\section{Conclusion}

Indicators of the quality of services provided by the PDAM of Tangerang City have a negative gap score. The perception value of the customer is smaller than expectations $(\mathrm{P}<\mathrm{E})$, meaning that the consumer gives a negative presumption for the water services received from the PDAM. The results indicate customer dissatisfaction. The gap between the services expected and the perceived services received shows that the quality of service organized by the Tangerang City PDAM has not been in line with expectations or needs of the customer.

The quality of service is not in accordance with the expectations of consumers, causing 
dissatisfaction reflecting that the consumer rights have not been fulfilled properly. Law number 8 the year 1999 on Consumer Protection has been set to regulate the rights of consumers. Consumer rights protection of the Tangerang City PDAM has not been fully materializing, among others the right to receive guidance and consumer education, and the right to compensation and/or replacement if the goods and/or services received were not in accordance with the agreement. The agreement between consumers and the PDAM did not include consumer rights but focuses more on some of the obligations that must be met by consumers. The implication is that when there is a loss on the part of the consumer, it would be difficult for the consumer to assert their rights to the PDAM because from the beginning the consumer has approved the contents of the affidavit. Article 46 paragraph 1, letter b of Law Number 8 Year 1999 with description mentions that the group of consumers who have an interest as well as the fact that the same may file a lawsuit against the perpetrators of the business class action. The similarity of interests and the facts can be seen from any agreements or evidence of the same. The consumer of the PDAM can, by means of a class action, files a lawsuit against any unlawful act perpetrated by The PDAM, as long as it was supported with enough evidence which proves the following: the action was conducted by the PDAM; the act was unlawful; the presence of violation in the PDAM actions; the element of customer losses; as well as the causal relationships between actions of PDAM with customer's losses.

\section{REFERENCES}

\section{A. Books}

Bates, John E. G. and Hoffman, Douglas, 1999, Managing Services Marketing: Text and Readings, The Dryden Press Harcourt Brace College Publisher, Orlando.

Creswell, John W., 2010, Research Design: Qualitative, Quantitative, and Mixed Approach, Pustaka Belajar, Yogyakarta.

Ghozali, Imam, 2005, Program Aplikasi Analisis Multivariate Dengan Program IBM SPSS, Universitas Diponegoro, Semarang.

Lovelock, Christopher, et al., 2001, Services Marketing: An Asia-Pacific Perspective $2^{\text {nd }}$ edition, Pearson Education, Sydney.

Nasution, A.Z., 1995, Konsumen dan Hukum, Pustaka Sinar Harapan, Jakarta.

Shidarta, 2000, Hukum Perlindungan Konsumen Indonesia, Grasindo, Jakarta.

Rangkuti, Freddy, 2002, Measuring Customer Satisfaction Teknik Mengukur dan Strategi Meningkatkan Kepuasan Konsumen, Gramedia Pustaka Utama, Jakarta.

Sinambela, Lijan Poltak, 2008, Reformasi Pelayanan Publik: Teori, Kebijakan dan
Implementasi, Bumi Aksara, Jakarta.

\section{B. Journal Articles}

Assegaf, Mohammad, "Pengaruh Kualitas Pelayanan Terhadap Kepuasan konsumen Studi Pada Perusahaan Penerbangan PT. Garuda Di Kota Semarang”, Jurnal Ekonomi dan Bisnis Unisulla Semarang, Vol. 10 No. 2, Juli 2009.

Atmawati, Rustika dan Wahyuddin, "Analisis Pengaruh Kualitas Pelayanan Terhadap Kepuasan Konsumen Pada Matahari Departement Store di Solo Grand Mall”, Jurnal Ekonomi Manajemen Sumber Daya, Vol. 5, No. 1, Juni 2004.

Nurcahyono, Arinto, et al, "Hak Atas Air dan Kewajiban Negara dalam Pemenuhan Akses terhadap Air", Jurnal Mimbar, Vol. 31, No. 2, Oktober 2015.

Pancawati, Juwarin, "Ketersediaan Lahan Resapan Air di Kota Tangerang", Jurnal Ilmu Pertanian dan Perikanan, Vol. 2 No. 1, Juni 2013.

Parasuraman, Valeri A., et al., "Conceptual Model 
of Service L. and Its Implications for Future Research", Journal of Marketing, No. 49, 1985.

Ranto, Dwi Wahyu Pril, "Pengaruh Kualitas Pelayanan Terhadap Kepuasan Pelanggan Berbelanja Pada Toko Modern di Yogyakarta",
Jurnal Bisnis Teori dan Implementasi, Vol. 6, No.1, Februari 2015.

\section{Article of Newspappers}

Redaktur Kompas, "Jutaan Sambungan jadi Syarat Penuhi Akses Air”, Kompas, 5 Maret 2015. 